\title{
Rancang Bangun Sistem Informasi BUMDes Giri Bangun Berbasis Website Menggunakan Metode Waterfall
}

\author{
Endah Ratna Sari ${ }^{1}$, Muhammad Abdul Aziz ${ }^{2}$ \\ ${ }^{1,2}$ Program Studi teknik Informatika, Universitas Ma'arif Nahdlatul Ulama Kebumen \\ $\underline{\text { sariratnaendah@gmail.com }}{ }^{1}$, dotacome@gmail.com ${ }^{2}$
}

\begin{abstract}
Abstrak
Sistem informasi BUMDes Giri Bangun berbasis website adalah sistem informasi yang digunakan untuk menyebarkan informasi dari BUMDes Giri Bangun sehingga tersebar luas dengan cepat dan mudah. Masalah yang dihadapi yaitu belum adanya sistem informasi BUMDes Giri Bangun berbasis website sehingga masyarakat kesulitan mengakses informasi secara online. Selain itu, penyebaran informasi BUMDes Giri Bangun masih dilakukan secara manual sehingga masyarakat masih kesulitan untuk mencari informasi BUMDes Giri Bangun. Tujuan dirancangnya sistem informasi BUMDes Giri Bangun yaitu merancang sistem informasi untuk BUMDes Giri Bangun berbasis website. Dalam penelitian ini menggunakan metode penelitian R\&D (Research and Development). Perancangan sistem ini menggunakan bahasa pemrograman PHP, metode waterfall dan menggunakan blackbox testing. Hasil penelitian disimpulkan bahwa penelitian ini menghasilkan rancang bangun sistem informasi BUMDes Giri Bangun berbasis website. Pengujian sistem yang dilakukan menggunakan blackbox testing berhasil dan berjalan baik. Berdasarkan analisis data dari pengujian website, sistem informasi ini mencapai 84,8\% yang masuk ke dalam kategori sangat baik menurut skala likert.
\end{abstract}

Kata kunci: Sistem informasi, website, metode waterfall, PHP

\begin{abstract}
The Information system of BUMDes Giri Bangun based on website is an information system that used to disseminate the information from BUMDes Giri Bangun so that it's widely spread quickly and easily. The problem faced is that there is no information system of BUMDes Giri Bangun based on website, so that the people have difficulty in accessing information online. Besides that, the dissemination of information on the BUMDes Giri Bangun still done by manually so the people get difficulty to find information on BUMDes Giri Bangun. The purpose of designing the BUMDes Giri Bangun information system is to design an information system for the website-based BUMDes Giri Bangun. In this study using research methods $R \& D$ (Research and Development). The design of this system uses the PHP programming language, the waterfall method and uses blackbox testing.The results of the study concluded that this study resulted in the design of a website-based BUMDes Giri Bangun information system. System testing carried out using blackbox testing was successful and went well. Based on data analysis from website testing, this information system reached $84.8 \%$ which was included in the very good category according to the Likert scale.
\end{abstract}

Keywords: Information system, website, waterfall method, PHP 


\section{Pendahuluan}

Sistem informasi merupakan suatu kombinasi teratur dari orang-orang, hardware, software, jaringan komunikasi dan sumber daya data yang mengumpulkan, mengubah, dan menyebarkan informasi dalam sebuah organisasi (Anggraeni \& Irviani, 2017). Nilai informasi yang berhubungan dengan teknologi berperan membantu pembuat keputusan untuk mencapai tujuan suatu organisasi, sehingga memungkinkan untuk meningkatkan pengendalian organisasi atau bisnisnya. Sekarang ini, informasi dapat diakses darimana saja dengan melalui internet. Perkembangan sistem informasi sekarang pun sangat berkembang dengan sangat cepat, tidak sedikit dari lembaga yang menggunakan sistem informasi untuk membantu kemudahan dalam bekerja. Salah satunya sistem informasi yang dikembangkan yaitu website.

Penggunaan sistem informasi di lembaga sudah banyak, namun di BUMDes Giri Bangun Desa Giripurno belum memiliki sistem informasi berbasis website yang digunakan sebagai penyebaran informasi ataupun sebagai pengenalan profil. Pengelolaan atau penyebaran informasi yang dilakukan masih manual dengan cara penyebaran informasi melalui grup whatsapp, surat, face to face yang diadakan di musyawarah desa setiap triwulan menyebabkan staf BUMDes menjadi kesulitan dengan hal itu.

Sistem yang berjalan belum mampu mencapai Misi BUMDes yang tercantum di Anggaran Dasar BUMDes Giri Bangun pasal 3 ayat (2) poin $b$ yang berbunyi memberikan pelayanan yang maksimal. Pelayanan yang masimal salah satu contohnya yaitu dalam penyampaian informasi atau berita-berita baru untuk masyarakat karena sistem yang dijalankan masih manual. Permasalahan tersebut dapat diatasi dengan perancangan sistem informasi berbasis website, sehingga sistem dapat digunakan oleh staf BUMDes untuk penyebaran informasi dan masyarakat dapat mengakses informasi dengan cepat dan mudah dengan menggunakan website.

Menurut penelitian sebelumnya oleh Armansyah (2018), menyatakan bahwa penggunaan teknologi informasi dan sistem informasi tersebut diharapkan mampu mendorong percepatan perputaran usaha dan operasional dan meningkatkan efisiensi dan efektivitas kerja setiap bagian. Dikarenakan belum adanya website sebagai sistem informasi BUMDes Giri Bangun menyebabkan penyebaran informasi dilakukan secara manual sehingga masyarakat kesulitan apabila megakses informasi secara online. Berdasarkan penelitian sebelumnya dari Abdulghani dan Solehudin (2018), menyatakan bahwa dengan belum adanya sistem informasi menyebabkan sulitnya desa menjadi desa yang berbasis IT serta kurangnya efisiensi aksebilitas kerja pengurus. Berdasarkan uraian yang dikemukakan, peneliti melakukan penelitian yang berjudul "Rancang Bangun Sistem Informasi BUMDes Giri Bangun Berbasis Website Menggunakan Metode Waterfall'. Penelitian ini diharapkan dapat digunakan untuk membantu staf BUMDes dalam penyebaran informasi ataupun pengenalan profil dari BUMDes itu sendiri. Selain itu, peneliti berharap masyarakat tidak lagi kesulitan untuk mengakses informasi BUMDes dengan melalui web. Perbedaan penelitian ini dari sebelumnya yaitu sistem informasi berbasis website menggunakan blackbox testing sehingga pengujian dalam 
penelitian hanya menilai sesuai dengan kebutuhan.

\section{Metodologi Penelitian}

Penelitian ini dilakukan pada BUMDes Giri Bangun yang berlokasi di Desa Giripurno RT 02/RW 02 Kecamatan Karanganyar Kabupaten Kebumen. BUMDes Giri Bangun merupakan Badan Usaha Milik Desa Giripurno yang telah berdiri sejak tahun 2016. Penelitian yang dilakukan yaitu menggunakan jenis penelitian Research and Development (R\&D). Dengan menggunakan jenis penelitian ini bertujuan untuk menghasilkan suatu produk dan menguji keefektifan produk tersebut.

Berdasarkan penelitian yang dilakukan oleh peneliti, BUMDes Giri Bangun masih kurang dalam penerapan sistem informasi berbasis website sebagai penyebaran informasi karena belum adanya sistem informasi BUMDes Giri Bangun berbasis website sehingga masyarakat kesulitan mengakses informasi secara online. Selain itu Penyebaran informasi BUMDes Giri Bangun masih dilakukan secara manual.

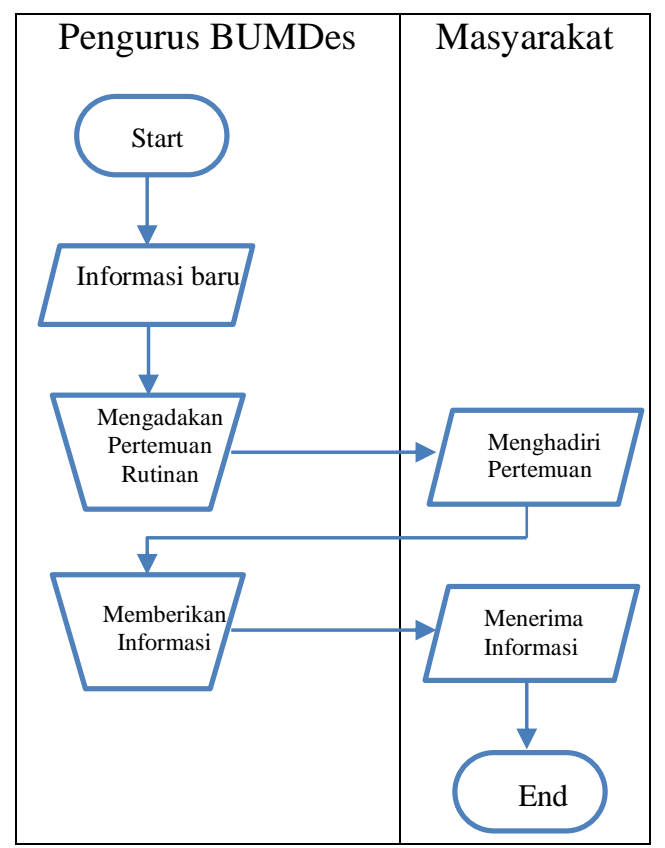

\section{Gambar 1 Flowchart Sistem yang Berjalan}

Setelah menganlisis sistem yang berjalan, selanjutnya penulis merancang sistem baru untuk memecahkan masalah yang ada di BUMDes Giri Bangun. Berikut

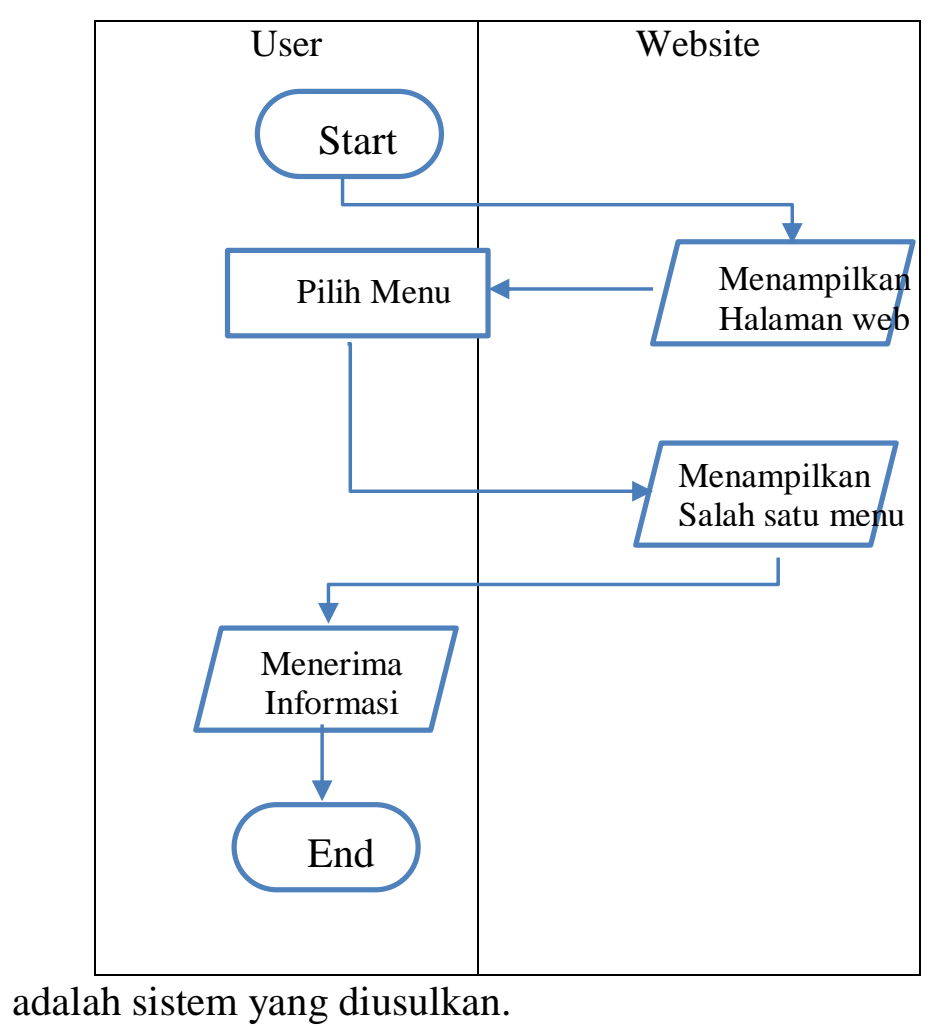

\section{Gambar 2 Flowchart Sistem yang Diusulkan}

\subsection{Metode Pengumpulan Data}


Penelitian ini menggunakan beberapa teknik pengumpulan data, antara lain sebagai berikut:

\subsubsection{Observasi}

Teknik pengambilan data dengan observasi yaitu aktivitas untuk mengetahui sesuatu dari fenomena-fenomena atau peristiwa berdasarkan pengetahuan atau gagasan yang bertujuan mendapatkan informasi dengan melakukan pengamatan secara langsung (Edra, 2017). Hasanah (2016:21-46) berpendapat dalam jurnalnya yang berjudul Teknik-Teknik Observasi, "Metode Observasi merupakan salah satu varian pilihan metode pengumpulan data yang memiliki karakter kuat secara metodologis".

\subsubsection{Studi Pustaka}

Penelitian kepustakaan atau studi pustaka adalah kegiatan penelitian dilakukan dengan cara mengumpulkan informasi dan data dengan bantuan berbagai macam material yang ada di perpustakaan seperti buku referensi, hasil penelitian sebelumnya yang sejenis, artikel, catatan, serta berbagai jurnal yang berkaitan dengan masalah yang ingin dipecahkan (Sari, 2020). Studi kepustakaan merupakan langkah yang penting dimana setelah seseorang peneliti menetapkan topik penelitian, langkah selanjutnya adalah melakukan kajian teoritis dan referensi yang terkait dengan penelitian yang dilakukan (Sugiyono, 2017).

\subsubsection{Kuesioner}

Pada tahap pengumpulan data ini yaitu dengan cara mengumpulkan informasi atau data dari banyak orang. Kuesioner ini digunakan pada saat pengujian sistem informasi berbasis website. Kegunaan pengumpulan data kuesioner pengujian ini digunakan untuk menguji kelayakan pada sistem atau berhasil tidaknya sistem saat diuji.

\subsection{Metode Waterfall}

Prosedur penelitian tentang perancangan sistem informasi berbasis website studi kasus di BUMDes Giri Bangun menggunakan metode waterfall. Berikut merupakan tahapan metode waterfall.

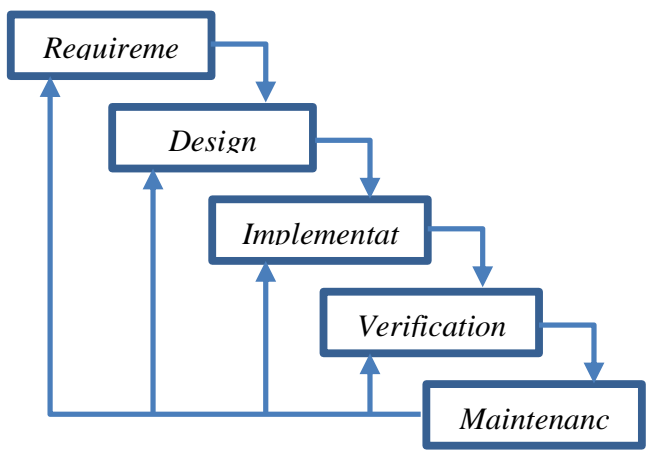

\section{Gambar 3 Skema Metode Waterfall}

Keterangan:

Prosedur pengembangan sistem informasi berbasis website penelitian untuk lebih jelasnya lagi terdapat pada tahapan berikut berdasarkan Gambar 3.

a. Requirement (Analisis)

Tahap analisis kebutuhan dilakukan bertujuan untuk mengetahui dibutuhkannya pengembangan sistem informasi berbasis website untuk BUMDes Giri Bangun. Pada tahap ini dilakukan analisis sistem yang berjalan dan analisis sistem yang diusulkan.

b. Design (Perancangan)

Pada tahap ini dilakukan perancangan sistem dimana akan memberikan solusi dari masalah yang muncul pada tahap analisis. Kerangka produk yang disusun sebagai pedoman untuk tahapan pengembanan dan implementasi diantaranya:

a) Flowchart yang berisi tentang alur dari sistem informasi berbasis website.

b) Use case diagram, activity diagram, dan sequence diagram

c) Perancangan tabel database

d) Storyboard yang merupakan sketsa yang berisi alur dalam sistem informasi berbasis website dari awal sampai akhir

c. Implementation (Penerapan)

Tahap Implementation atau penerapan, tahapan ini sistem 
diimplementasikan pada perangat keras dan penyusunan desain (coding).

d. Verification (Pengujian)

Tahap ini dilakukan pengujian sistem yang sudah berjalan sesuai dengan rencana yang sudah disusun sebelumnya, termasuk apabila terjadi error atau tidak. Tahap pengujian dilakukan dengan menguji coba sistem informasi berbasis website kepada masyarakat. Uji coba ini bertujuan untuk mengetahui respon dari masyarakat atau pengguna terdapat sistem informasi berbasis website yang dikembangkan.

e. Maintenance (Pemeliharaan)

Pada tahap ini dilakukan pemeliharan sistem yang sudah diujikan dan dijalankan.

\section{Implementasi Dan Pembahasan}

Pada tahap ini merupakan tahapan yang penting dimana sistem yang telah dirancang lalu diimplementasikan ke dalam program. Pada tahap ini dilakukan beberapa penerapan yaitu pembuatan basis data. Pengimpelementasian basis data menggunakan $M y S Q L$ yang terdapat pada software XAMPP.

\subsection{Implementasi Basis Data}

Basis Data pada sistem informasi ini menggunakan MySQL yang memiliki 24 tabel dengan nama basis data db_bumdes. Sistem Informasi BUMDes Giri Bangun akan menjadi record dari pengelolaan yang ditampung ke database.

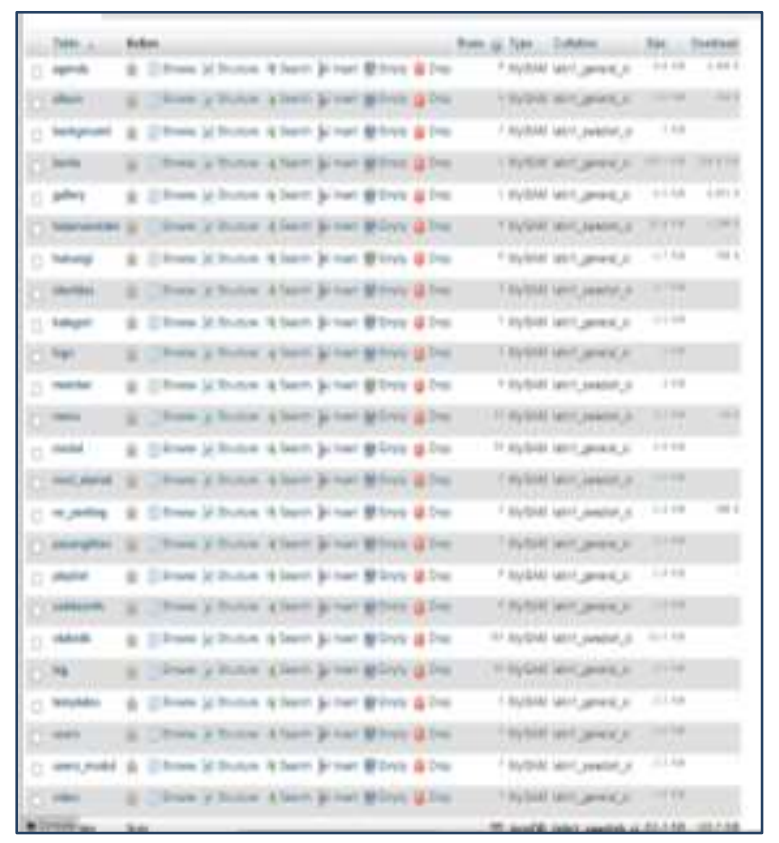

Gambar 4 Implementasi Basis Data

\subsection{Implementasi Website}

3.2.1. Tampilan Antarmuka Admin

Pada halaman administrator ini digunakan untuk mengelola website pada halaman user/pengguna. Pada halaman ini hanya dapat diakses oleh admin yang sudah mempunyai username serta password yang nantinya akan dimasukkan di halaman login. Terdapat beberapa tampilan dan menu utama yang ada pada halaman administrator yaitu sebagai berikut:

1) Halaman Login

2) Halaman Administrator yang terdapat beberapa menu utama yaitu menu utama (web), modul berita, modul video, modul iklan, modul web dan modul user.

Setiap menu mempunyai fungsi masing masing, namun fungsi utama pada menu tersebut yaitu dapat menambahkan, mengedit dan menghapus data yang akan atau telah diunggah. Selain itu terdapat menu lain pada halaman administrator seperti profil, tombol lihat web dan tombol logout.

\subsubsection{Tampilan Antarmuka User/Pengguna}

Terdapat beberapa menu yang ada pada halaman antarmuka user/pengguna sistem 
informasi berbasis website ini diantaranya yaitu ikon social media, breaking news, beranda, profil, visi dan misi, struktur organisasi, berita dan kontak kami.

1) Tampilan Halaman Beranda

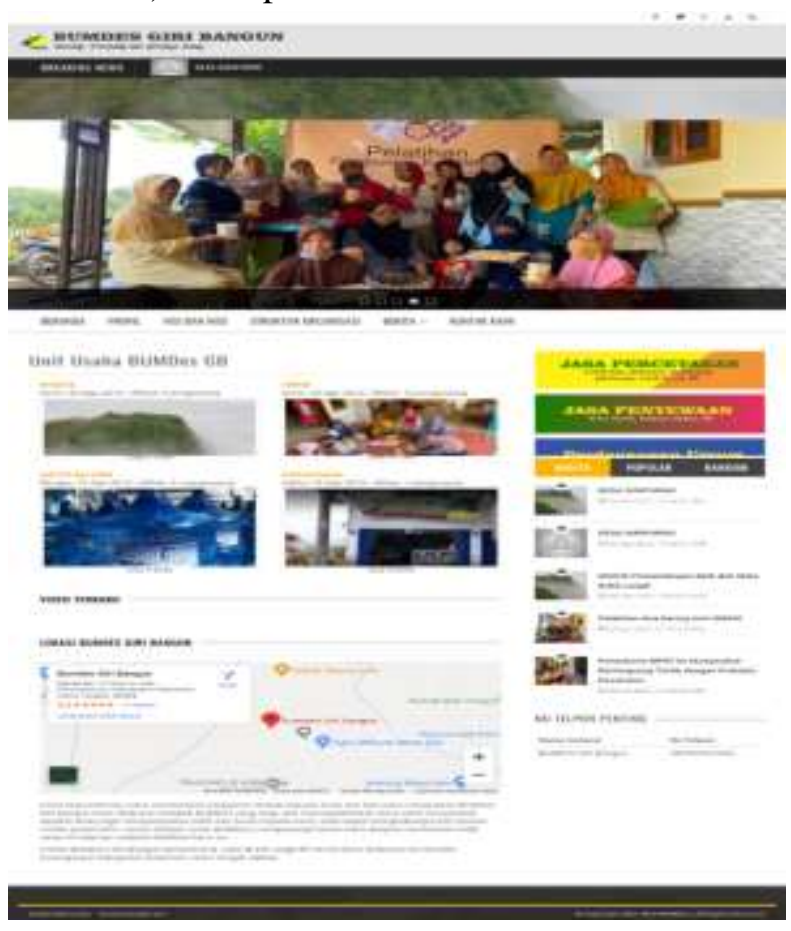

Gambar 5 Tampilan Halaman Beranda

2) Tampilan Halaman Profil

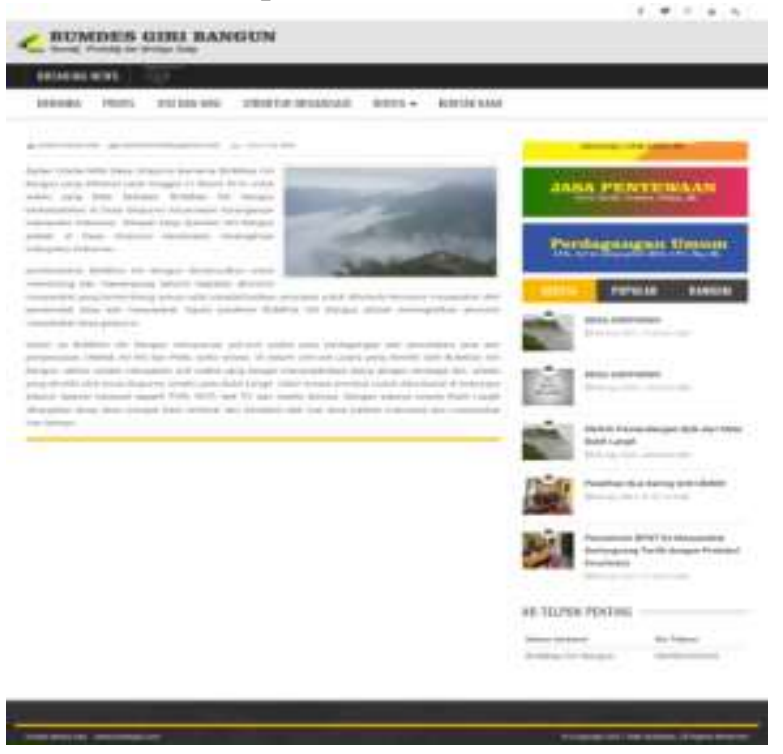

Gambar 6 Tampilan Halaman Profil

3) Tampilan Halaman Visi dan Misi

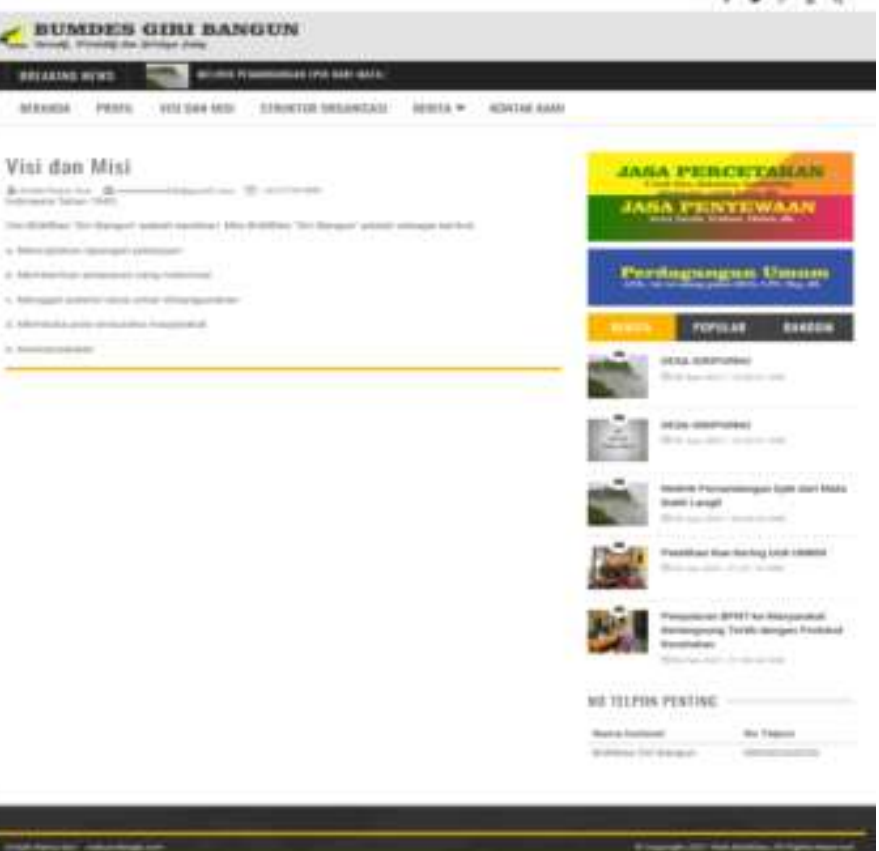

\section{Gambar 7 Tampilan Halaman Visi dan Misi}

4) Tampilan Halaman Struktur Organisasi

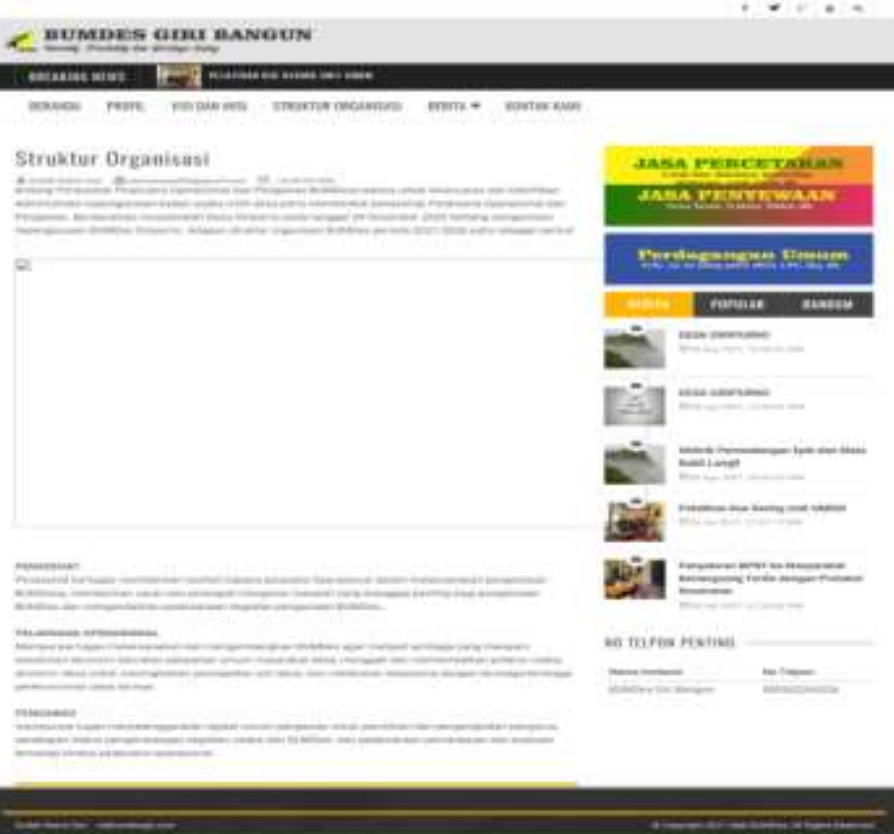

\section{Gambar 8 Tampilan Halaman Struktur Organisasi}

5) Tampilan Halaman Berita 


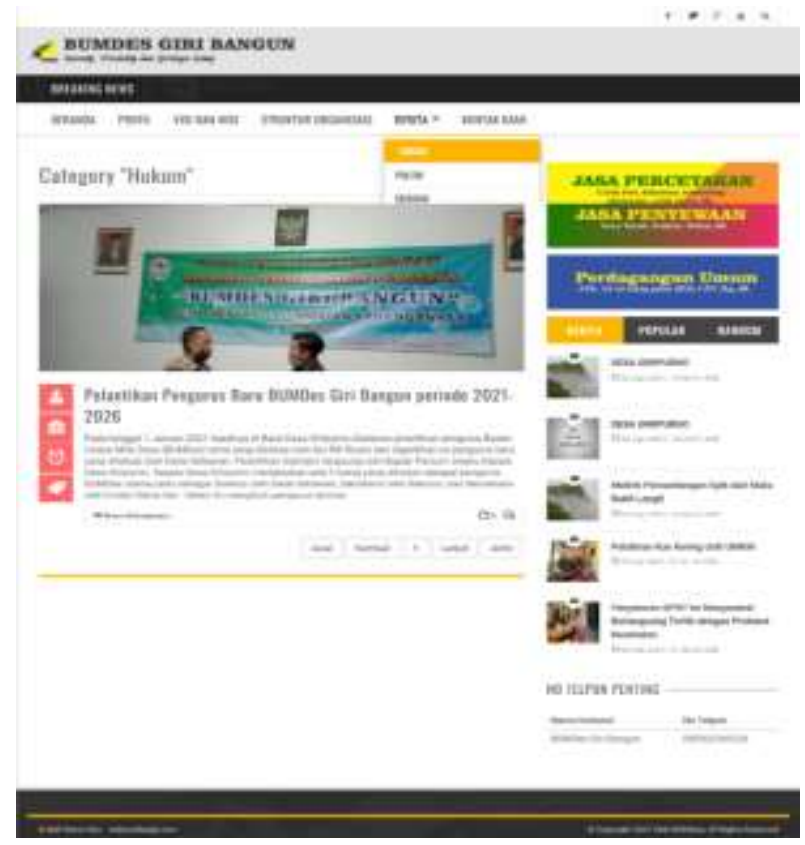

Gambar 9 Tampilan Halaman Berita

6) Tampilan Halaman Kontak Kami

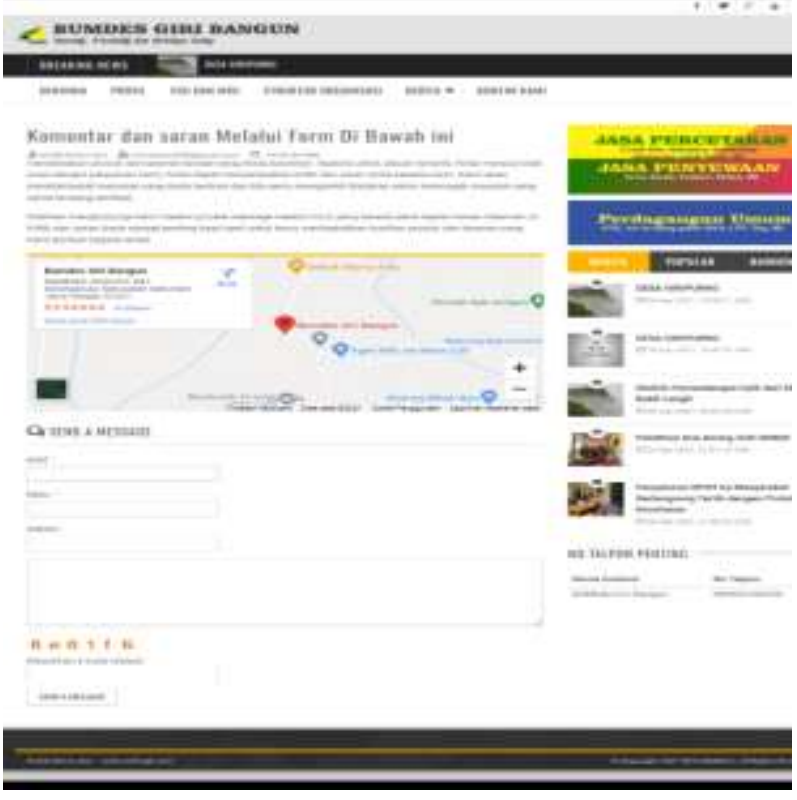

\section{Gambar 10 Tampilan Halaman Kontak} Kami

\subsection{Pengujian}

Pengujian sistem informasi ini menggunakan Black Box Testing untuk user dan Black Box Testing untuk admin. Black Box Testing ini lebih menguji ke tampilan luar dari website yang dirancang agar mudah digunakan oleh pengguna.
Pengujian ini dilakukan untuk mengetahui apakah fungsi pada menu berfungsi dengan baik atau terdapat beberapa kesalahan.

Tabel 1 Hasil Pengujian Halaman Admin

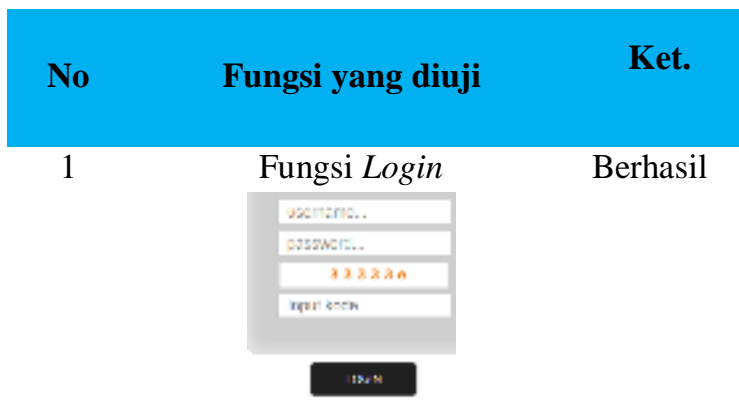

$2 \quad$ Fungsi pesan error pada Berhasil login

3 Menu-menu pada halaman Berhasil administrator

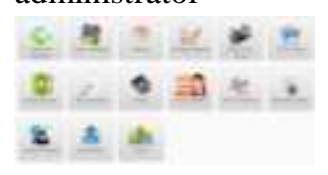

4

Fungsi tambah, simpan, edit Berhasil dan hapus

$$
\text { Tambahkan Berita }
$$

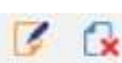

5

$$
\text { Fungsi Lihat Web }
$$

Berhasil

$$
\text { Fungsi logout }
$$

Berhasil
Tabel 2 Hasil Pengujian Halaman User/Pengguna

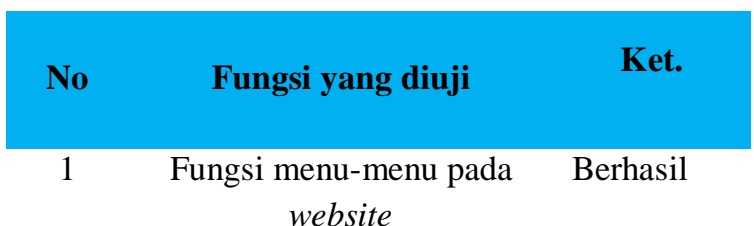


2

Judul berita

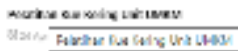

3

Fungsi search

Q

4

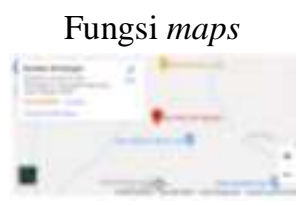

5

Fitur pesan

6

Ikon-ikon social media

Berhasil

Berhasil

Berhasil

Berhasil

Berhasil

\subsection{Analisis Data}

Proses analisis data dari penilaian pengguna merupakan langkah yang dilakukan setelah melakukan uji coba. Berikut merupakan hasil dari kuesioner yang diberikan kepada 25 responden dengan 14 pertanyaan disajikan pada Tabel 4 berikut.

\section{Tabel 3 Analisis Data Pengujian}

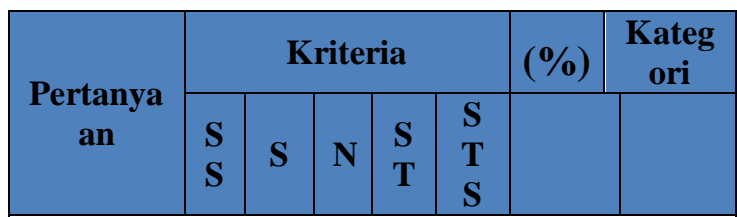

\section{Halaman Admin}

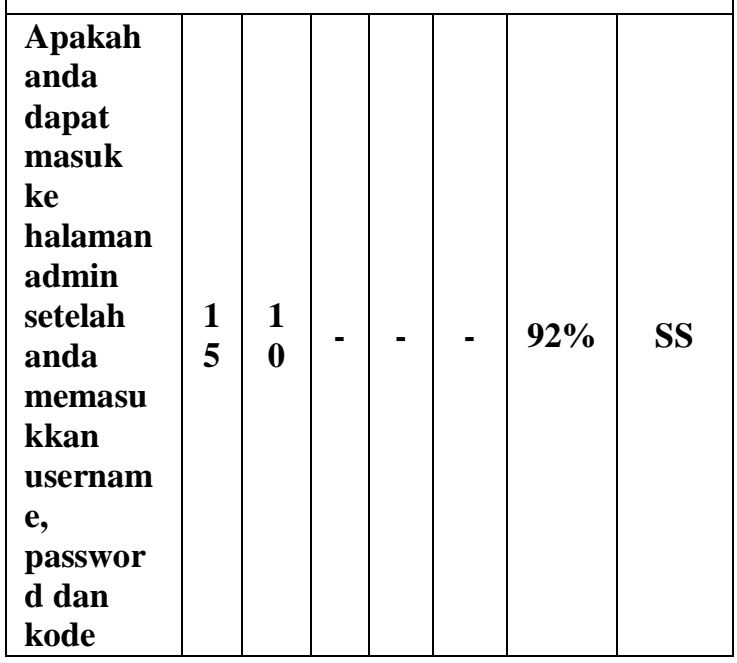

\begin{tabular}{|c|c|c|c|c|c|c|c|}
\hline captcha? & & & & & & & \\
\hline $\begin{array}{l}\text { Apakah } \\
\text { jika } \\
\text { anda } \\
\text { salah } \\
\text { memasu } \\
\text { kkan } \\
\text { usernam } \\
\text { e, } \\
\text { passwor } \\
\text { d atau } \\
\text { kode } \\
\text { captcha } \\
\text { akan } \\
\text { muncul } \\
\text { pesan } \\
\text { error? }\end{array}$ & 8 & $\begin{array}{l}1 \\
7\end{array}$ & - & - & - & $\begin{array}{c}\mathbf{8 6 , 4} \\
\%\end{array}$ & SS \\
\hline $\begin{array}{l}\text { Apakah } \\
\text { menu- } \\
\text { menu } \\
\text { yang } \\
\text { ditampil } \\
\text { kan } \\
\text { mudah } \\
\text { untuk } \\
\text { dipaham } \\
\text { i? }\end{array}$ & - & $\begin{array}{l}1 \\
1\end{array}$ & 7 & 7 & - & $\begin{array}{c}\mathbf{6 3 , 2} \\
\%\end{array}$ & $\mathbf{S}$ \\
\hline $\begin{array}{l}\text { Apakah } \\
\text { saat } \\
\text { menu } \\
\text { yang } \\
\text { anda } \\
\text { klik } \\
\text { dapat } \\
\text { menamp } \\
\text { ilkan } \\
\text { halaman } \\
\text { tersebut } \\
\text { dengan } \\
\text { cepat? }\end{array}$ & 1 & 9 & 9 & 6 & - & $\begin{array}{c}\mathbf{5 9 , 2} \\
\%\end{array}$ & $\mathbf{N}$ \\
\hline $\begin{array}{l}\text { Apakah } \\
\text { anda } \\
\text { dapat } \\
\text { menamb } \\
\text { ahkan, } \\
\text { menyim } \\
\text { pan, } \\
\text { menghap } \\
\text { us } \\
\text { ataupun } \\
\text { mengedit } \\
\text { data di } \\
\text { menu } \\
\text { yang }\end{array}$ & 3 & $\begin{array}{l}2 \\
1\end{array}$ & 3 & - & - & $\begin{array}{c}\mathbf{8 1 , 6} \\
\%\end{array}$ & SS \\
\hline
\end{tabular}




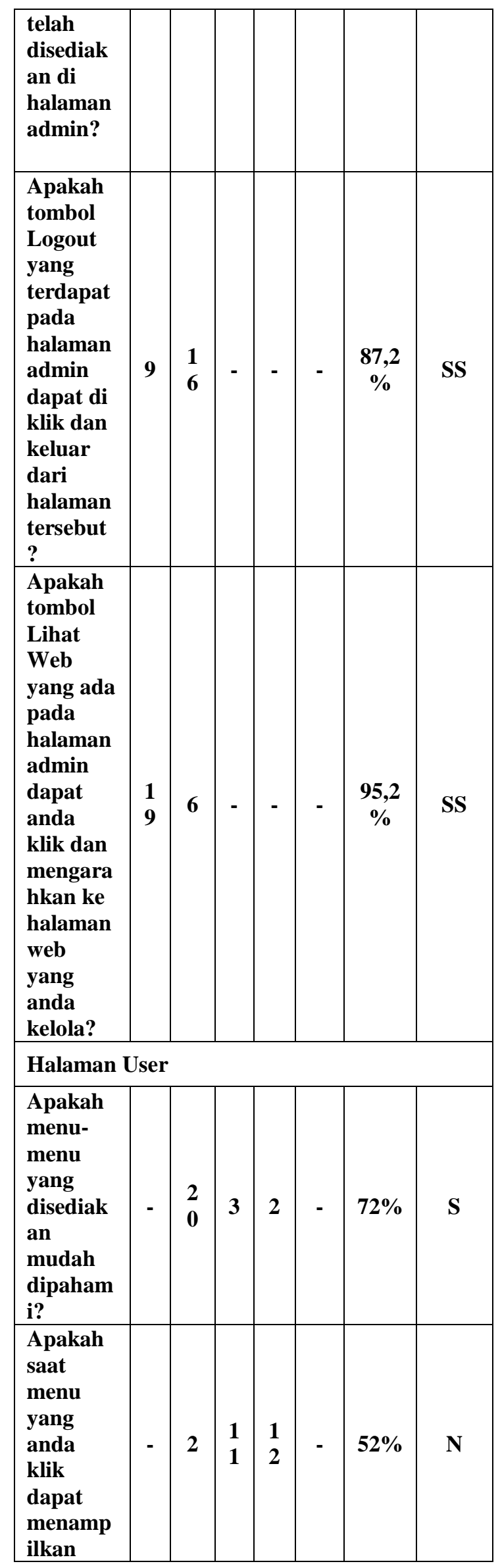

\begin{tabular}{|c|c|c|c|c|c|c|c|}
\hline $\begin{array}{l}\text { halaman } \\
\text { tersebut } \\
\text { dengan } \\
\text { cepat? }\end{array}$ & & & & & & & \\
\hline $\begin{array}{l}\text { Apakah } \\
\text { judul } \\
\text { berita } \\
\text { yang } \\
\text { anda } \\
\text { klik } \\
\text { akan } \\
\text { dapat } \\
\text { menamp } \\
\text { ilkan } \\
\text { halaman } \\
\text { tersebut } \\
\text { dengan } \\
\text { cepat? }\end{array}$ & - & $\begin{array}{l}1 \\
0\end{array}$ & 8 & 7 & - & $\begin{array}{c}\mathbf{6 2 , 4} \\
\%\end{array}$ & $\mathbf{S}$ \\
\hline $\begin{array}{l}\text { Apakah } \\
\text { judul } \\
\text { dapat } \\
\text { langsung } \\
\text { ditampil } \\
\text { kan } \\
\text { apabila } \\
\text { diketika } \\
\text { n pada } \\
\text { fitur } \\
\text { search } \\
\text { (mesin } \\
\text { pencari) } \\
\text { ? }\end{array}$ & 1 & \begin{tabular}{|l}
2 \\
0
\end{tabular} & 2 & 2 & - & $76 \%$ & $\mathbf{S}$ \\
\hline $\begin{array}{l}\text { Apakah } \\
\text { lokasi } \\
\text { yang } \\
\text { disediak } \\
\text { an pada } \\
\text { halaman } \\
\text { website } \\
\text { berfungs } \\
\text { i dengan } \\
\text { baik? }\end{array}$ & 5 & \begin{tabular}{|l|}
2 \\
0
\end{tabular} & - & - & - & $84 \%$ & SS \\
\hline $\begin{array}{l}\text { Apakah } \\
\text { anda } \\
\text { dapat } \\
\text { menggun } \\
\text { akan } \\
\text { fitur } \\
\text { pesan } \\
\text { yang ada } \\
\text { pada } \\
\text { halaman } \\
\text { website? }\end{array}$ & $\begin{array}{l}1 \\
1\end{array}$ & $\begin{array}{l}1 \\
4\end{array}$ & - & - & - & $\begin{array}{c}\mathbf{8 8 , 8} \\
\%\end{array}$ & SS \\
\hline $\begin{array}{l}\text { Apakah } \\
\text { ikon- } \\
\text { ikon lain } \\
\text { seperti } \\
\text { social } \\
\text { media } \\
\end{array}$ & 1 & $\begin{array}{l}2 \\
4\end{array}$ & $\begin{array}{l}3 \\
\mathbf{0}\end{array}$ & $\begin{array}{l}1 \\
4\end{array}$ & - & $\begin{array}{c}\mathbf{5 9 , 2} \\
\%\end{array}$ & $\mathbf{N}$ \\
\hline
\end{tabular}




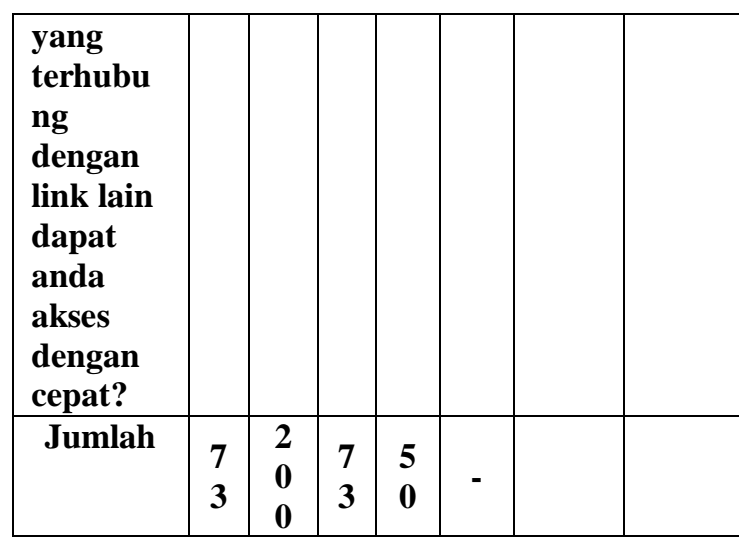

Berdasarkan Tabel 4 dapat disimpulkan bahwa rata-rata responden memberikan penilaian sangat setuju, setuju dan netral pada setiap pertanyaan yang diberikan pada kuesioner. Sedangkan analisis data penilaian pengguna secara keseluruhan terhadap sistem informasi berbasis website yaitu sebagai berikut dengan presentase perhitungan skor rata-rata penilaian website.

$\begin{array}{lll}\text { Nilai } 5: & 73 * 5 & =365 \\ \text { Nilai } 4: & 200 * 4 & =800 \\ \text { Nilai } 3: & 73 * 3 & =219 \\ \text { Nilai } 2: & 50 * 2 & =100 \\ \text { Nilai } 1: \quad 1 * 0 & =0 \\ & \text { Jumlah } & =1484 \\ \text { Jumlah data } & =25 \\ \text { Jumlah pertanyaan } & =14 \\ \text { Data tertinggi } & =5 * 14 * 25 \\ \text { = 1750 } & \\ \text { Data terendah } & =1 * 14 * 25 \\ =350 & \end{array}$

Presentase penilaian = $\frac{\text { data hasil penelitian }}{\text { data tertinggi }} \times 100 \%$ $=\frac{1484}{1750} \times 100 \%$ $=84,8 \%$

Dari hasil perhitungan di atas, hasil skor yang didapatkan yaitu $84,8 \%$ dan berdasarkan tabel penilaian skala likert, maka sistem informasi berbasis website masuk ke dalam kategori "sangat baik".

\section{Simpulan}

Berdasarkan hasil penelitian dan pembasahan yang berjudul tentang rancang bangun sistem informasi BUMDes Giri Bangun berbasis website menggunakan metode waterfall maka dapat disimpulkan bahwa penelitian yang menggunakan metode waterfall dan bahasa pemrograman PHP ini menghasilkan sistem informasi BUMDes Giri Bangun yang berbasis website. Sistem informasi ini yang dapat digunakan oleh staf BUMDes dan masyarakat yang membutuhkan informasi mengenai BUMDes.

Perancangan sistem informasi ini ini dilakukan pengujian dengan menggunakan blackbox testing yang berfokus pada uji fungsi sistem informasi oleh staf BUMDes dan masyarakat dengan hasil baik dan berhasil. Berdasarkan hasil dari data kuesioner pengujian sistem informasi berbasis website dari pengguna, sistem informasi ini masuk ke dalam kategori sangat baik dengan presentase $84,8 \%$.

\section{DAFTAR PUSTAKA}

Abdulghani, T., \& Solehudin, T. (2018). Sistem Informasi Pengelolaan Administratif Badan Usaha Milik Desa (BUMDes) Berbasis Client Server. Jurnal Ilmiah Santika, 8(2), 241-254.

Anggraeni, E. Y., \& Irviani, R. (2017). Pengantar Sistem Informasi. Yogyakarta: CV. ANDI OFFSET.

Edra, R. (2017, November 13). 10 Pengertian Observasi Menurut Para Ahli. Diakses Juni 5, 2021, dari Ruang Guru: https://www.ruangguru.com/blog/10pengertian-observasi-menurut-para-ahli 
26 Jurnal Riset Teknologi Informasi dan Komputer (JURISTIK), Vol. 1, No. 1, Juni 2021, hlm. 16-26

Hasanah, H. (2016). Teknik-Teknik Observasi. at-Tagaddum, 8(1), 21-46.

Sari, M. (2020). Penelitian Kepustakaan (Library Research). Natural Science, 6(1), 41-53.

Sugiyono. (2017). Metode Penelitian Kuantitatif, Kualitatid dan $R \& D$. Bandung: CV Alfabeta. 